\title{
Effect of metformin on semen quality
}

\author{
Saleem Ali Banihani \\ Department of Medical Laboratory Sciences, Jordan University of Science and Technology, Irbid, Jordan
}

\begin{abstract}
Various studies have linked metformin, a universally antidiabetic drug, with semen quality; however, such a direct link has not been established. This review systematically addresses and summarizes the effect of metformin on semen quality, particularly sperm function. We searched the MEDLINE electronic database for English articles and abstracts containing the key words 'metformin' and 'sperm', and relevant articles were reviewed. In summary, metformin appears to have improved and provided positive impact on sperm quality. This effect may be due to the ability of metformin to reduce oxidative stress and lipid peroxidation, enhance 5'-AMP activated protein kinase activity, and restore the normal levels of pituitary-gonadal hormones. However, further clinical research is still necessary to confirm such effect.
\end{abstract}

Uniterms: Metformin/effects. Metformin/review. Metformin/semen quality. Sperm/study. Testosterone. Oxidative stress. 5'-AMP activated protein kinase.

\section{INTRODUCTION}

Metformin, a biguanide-derivative antidiabetic drug, is the most widely used oral agent in humans (Brinkmann, Brixius, 2015; Chhetri, Thapa, Van Schepdael, 2014). It is the first-line drug for the treatment of type 2 diabetes, particularly, in overweight and obese patients with normal kidney function (American Diabetes, 2009; George, Joseph, 2014; Hung et al., 2015). In addition, recent research has proposed that metformin alone or in combination with insulin may be safe to treat gestational diabetes and does not increase the risk of metabolic acidosis (Huang, Castelino, Peterson, 2015; Kitwitee et al., 2015). Metformin's mechanism of action involves suppression of hepatic gluconeogenesis (Ferrannini, 2014; Foretz et al., 2010; Todd, Florez, 2014). One concern that has been raised relevant to metformin usage is that the consensus panel of diabetes felt that metformin should be considered for diabetes prevention even in non-diabetic individuals (i.e., pre-diabetic or obese individuals). This concern increases the use of this drug by these groups (American Diabetes, 2009; Hostalek, Gwilt, Hildemann, 2015; Manu et al., 2015; McGavock, Dart, Wicklow, 2015).

\footnotetext{
*Correspondence: S. A. Banihani. Biomedical sciences/Clinical bio-analytical chemistry. Department of Medical Laboratory Sciences. Jordan University of Science and Technology, P.O. Box: 3030 - Irbid- 22110 - Jordan. E-mail: sabanihani@just.edu.jo
}

Over the last decade, various experimental and clinical studies have linked metformin with sperm function, and thus with male factor infertility (Alves et al., 2014; Ferreira et al., 2015); however, such direct link has not been established. In this review, we provide fresh and comprehensive understanding of the effect of metformin, as a universally used oral agent, on semen quality (i.e., sperm quantity and quality). To do this, we searched the MEDLINE electronic database for English-language articles and abstracts reported using the key words 'metformin' and 'sperm'. The references from selected articles were reviewed and used if relevant.

\section{Effect of metformin on sperm parameters}

\section{Positive effects}

To date, the majority of studies linking metformin to sperm parameters are nonclinical. In his study on streptozotocin-induced diabetic rats, Attia, Helal, Alhaider (2009) made the seminal observation that metformin decreases the diabetes-induced genomic instability and cell proliferation changes in germinal cells in a dosedependent manner $(2500,500,>100 \mathrm{mg} / \mathrm{kg}$ ) (Attia, Helal, Alhaider, 2009). Later in vivo system study on diabetic rats clearly showed that oral treatment with metformin $(50$ $\mathrm{mg} / \mathrm{kg} / \mathrm{day}$, for 4 weeks) in combination with pioglitazone, another antidiabetic drug, at $1 \mathrm{mg} / \mathrm{kg}$ increases the caudal sperm count and decreases sperm morphology defects 
(Rabbani, Devi, Khanam, 2010). Moreover, epididymal sperm count, motility, and morphology were improved in diabetic rats upon treatment with metformin at $30 \mathrm{mg} / \mathrm{kg} /$ day for 6 weeks (Adaramoye, Lawal, 2014). Furthermore, diet-induced obesity rats fed orally with metformin for 12 weeks had higher epididymal sperm count and motility (Fang et al., 2012).

Further, a number of in vitro studies have revealed positive effects of metformin on sperm parameters. Adding metformin at $50 \mu \mathrm{M}$ to cryopreservation media of mouse semen improved the quality (motility and morphology) of frozen sperm (Bertoldo et al., 2014). A recent study conducted by Nguyen et al. (2014) showed that metformin enhances chicken sperm motility and viability, and increases acrosome reaction and lactate production (Nguyen et al., 2014).

The clinical study that displays the effect of metformin on sperm parameters was recently conducted by Bosman et al. (2014) on hyperinsulinaemic men (Bosman et al., 2014). This group showed that administration of metformin at the therapeutic dose improves sperm morphology (from $3.9 \%$ to $5.5 \%$ ) and enhances chromatin packaging quality by about $8.3 \%$ (Bosman et al., 2014).

\section{Negative effects}

Until now, only few reports have displayed negative effects of metformin on semen quality. Oral treatment of male rats with metformin at $30 \mathrm{mg} / \mathrm{kg} /$ day for 3 weeks decreased epididymal sperm count and motility by $34 \%$ and $31 \%$, respectively; while sperm live/dead ratio did not change using this treatment (Adaramoye et al., 2012). An in vitro study conducted by Adaramoye et al. (2012) to determine the toxic effects of metformin on mouse sperm observed a slight decrease in sperm motility when using high concentrations of metformin $(5000 \mu \mathrm{M})$; while using low concentration $(50 \mu \mathrm{M})$ of metformin did not induce any change in sperm quality (i.e., count, motility) (Bertoldo et al., 2014).

\section{Studies on the pharmaceutical action of metformin}

\section{Positive effects}

The mechanisms by which metformin induces the positive effects on sperm quality have been explained in a number of published articles. One obvious mechanism is that metformin reduces the level of oxidative stress (Banihani et al., 2014), an imbalance between oxidants and antioxidants to the favor of the former, and lipid peroxidation (Attia, Helal, Alhaider, 2009). It has been shown that metformin supplementation at $30 \mathrm{mg} / \mathrm{kg}$ restores the antioxidant function such as reduced glutathione, superoxide dismutase, catalase, glutathione peroxidase, and glutathione-S-transferase in diabetic male rats (Adaramoye, Lawal, 2014). Similar findings of enhancing the antioxidant function were observed when using diet-induced obesity rats (i.e., higher superoxide dismutase and glutathione peroxidase, and lower malondialdehyde) (Fang et al., 2012). In fact, metformin was identified as having antioxidant activity against oxidative damage by reactive oxygen species (Cahova et al., 2015; Ouslimani et al., 2005).

Moreover, metformin was found to enhance the phosphorylation of 5'-AMP activated protein kinase (AMPK), which is a sensor protein of cellular energy status, thus, a strategic enzyme in regulating energy balances (i.e., glucose and lipid metabolism) (Bertoldo et al., 2015; Hardie et al., 2003; Ma et al., 2015; Nguyen et al., 2014, 2015). Therefore, metformin may improve sperm function via enhancing the activity of AMPK.

Furthermore, some in vivo system studies have discussed the effect of metformin on pituitary-gonadal hormones. The study conducted by Adaramoye and Lawal (2014) on diabetic male rats showed that metformin is able to restore follicle-stimulating hormone, leutinizing hormone, and testosterone (Adaramoye, Lawal, 2014). Likewise, oral administration of metformin succeeded to restore testosterone level back to normal in diabetic rats (Ayuob, Murad, Ali, 2015).

\section{Negative effects}

In contrast, the clinical study conducted by Ozata et al. (2001) concluded that metformin use in combination with a hypocaloric diet decreases free testosterone and sex-hormone-binding globulin levels in nondiabetic obese men, and decreases total testosterone levels in obese patients with type 2 diabetes (Ozata et al., 2001).

\section{CONCLUSIONS AND FUTURE PERSPECTIVES}

To date, the mainstream of research is presenting positive effects of metformin on semen quality and sperm function, though there will still few reports that have deliberated some negative effects. Consequently, metformin, typically at the therapeutic dose, appears to be encouraging when considering its direct effect on semen quality and sperm function. Such effect may be due to the ability of metformin to reduce the oxidative damage and lipid peroxidation, enhance AMPK activity, and restore the normal levels of pituitary-gonadal hormones. While, with further studies, mainly clinical, are still of great importance to confirm these effects. Our laboratory is 
currently running a clinical study, using flow cytometry, to standardize the favorable and unfavorable concentrations of metformin to human sperm, particularly to the DNA of human sperm.

\section{ACKNOWLEDGMENT}

This study was supported by the deanship of research at Jordan University of Science and Technology grant no. 20150176.

\section{REFERENCES}

ADARAMOYE, O.; AKANNI, O.; ADESANOYE, O.; LABOPOPOOLA, O.; OLAREMI, O. Evaluation of toxic effects of metformin hydrochloride and glibenclamide on some organs of male rats. Niger. J. Physiol. Sci., v.27, n.2, p.137144, 2012.

ADARAMOYE, O.A.; LAWAL, S.O. Effect of kolaviron, a biflavonoid complex from Garcinia kola seeds, on the antioxidant, hormonal and spermatogenic indices of diabetic male rats. Andrology, v.46, n.8, p.878-886, 2014.

ALVES, M.G.; MARTINS, A.D.; VAZ, C.V.; CORREIA, S.; MOREIRA, P.I.; OLIVEIRA, P.F.; SOCORRO, S. Metformin and male reproduction: effects on Sertoli cell metabolism. Br. J. Pharmacol., v.171, n.4, p.1033-1042, 2014.

AMERICAN DIABETES. A Standards of medical care in diabetes-2009. Diab. Care, v.32, Suppl.1, p.S13-61, 2009.

ATTIA, S.M.; HELAL, G.K.; ALHAIDER, A.A. Assessment of genomic instability in normal and diabetic rats treated with metformin. Chem. Biol. Interact., v.180, n.2, p.296304, 2009.

AYUOB, N.N.; MURAD, H.A.; ALI, S.S. Impaired expression of sex hormone receptors in male reproductive organs of diabetic rat in response to oral antidiabetic drugs. Folia. Histochem. Cytobiol., v.53, n.1, p.35-48, 2015.

BANIHANI, S.; AGARWAL, A.; SHARMA, R.; BAYACHOU, M. Cryoprotective effect of L-carnitine on motility, vitality and DNA oxidation of human spermatozoa. Andrology, v.46, n.6, p.637-641, 2014.

BERTOLDO, M.J.; FAURE, M.; DUPONT, J.; FROMENT, P. AMPK: a master energy regulator for gonadal function. Front. Neurosci., v.9, p.235- 245, 2015.
BERTOLDO, M.J.; GUIBERT, E.; TARTARIN, P.; GUILLORY, $\mathrm{V}$; FROMENT, P. Effect of metformin on the fertilizing ability of mouse spermatozoa. Cryobiology, v.68, n.2, p.262-268, 2014.

BOSMAN, E.; ESTERHUIZEN, A.D.; RODRIGUES, F.A.; BECKER, P.J.; HOFFMANN, W.A. Effect of metformin therapy and dietary supplements on semen parameters in hyperinsulinaemic males. Andrology, v.47, n.9, p.974-979, 2014.

BRINKMANN, C.; BRIXIUS, K. Hyperlactatemia in type 2 diabetes: Can physical training help? J. Diab. Complic., v.29, n.7, p.965-969, 2015.

CAHOVA, M.; PALENICKOVA, E.; DANKOVA, H.; STICOVA, E.; BURIAN, M.; DRAHOTA, Z.; CERVINKOVA, Z.; KUCERA, O.; GLADKOVA, C.; STOPKA, P.; KRIZOVA, J.; PAPACKOVA, Z.; OLIYARNYK, O.; KAZDOVA, L. Metformin prevents ischemia reperfusion-induced oxidative stress in the fatty liver by attenuation of reactive oxygen species formation. Am. J. Physiol. Gastrointest. Liver Physiol., v.309, n.2, p.100-111, 2015.

CHHETRI, H.P.; THAPA, P.; VAN SCHEPDAEL, A. Simple HPLC-UV method for the quantification of metformin in human plasma with one step protein precipitation. Saudi Pharm. J., v.22, n.5, p.483-487, 2014.

FANG, X.; XU, Q.Y.; JIA, C.; PENG, Y.F. [Metformin improves epididymal sperm quality and antioxidant function of the testis in diet-induced obesity rats]. Zhonghua Nan. Ke. Xue., v.18, n.2, p.146-149, 2012.

FERRANNINI, E. The target of metformin in type 2 diabetes. N. Engl. J. Med., v.371, n.16, p.1547-1548, 2014.

FERREIRA, C.; RABACA, A.; SOUSA, M.; OLIVEIRA, P.F.; ALVES, M.G.; SA, R. Impact of metformin on male reproduction. Curr. Pharm. Des., v.21, n.25, p.3621-3633, 2015.

F ORETZ, M.; HEBRARD, S.; LECLERC, J . ; ZARRINPASHNEH, E.; SOTY, M.; MITHIEUX, G.; SAKAMOTO, K.; ANDREELLI, F.; VIOLLET, B. Metformin inhibits hepatic gluconeogenesis in mice independently of the LKB1/AMPK pathway via a decrease in hepatic energy state. J. Clin. Invest., v.120, n.7, p.23552369, 2010. 
GEORGE, R.E.; JOSEPH, S. A review of newer treatment approaches for type-2 diabetes: Focusing safety and efficacy of incretin based therapy. Saudi Pharm. J., v.22, n.5, p.403$410,2014$.

HARDIE, D.G.; SCOTT, J.W.; PAN, D.A.; HUDSON, E.R. Management of cellular energy by the AMP-activated protein kinase system. FEBS Lett., v.546, n.1, p.113-120, 2003.

HOSTALEK, U.; GWILT, M.; HILDEMANN, S. Therapeutic use of metformin in prediabetes and diabetes prevention. Drugs, v.75, n.10, p.1071-1094, 2015.

HUANG, W.; CASTELINO, R.L.; PETERSON, G.M. Adverse event notifications implicating metformin with lactic acidosis in Australia. J. Diab. Complic., v.29, n.8, p.1261$1265,2015$.

HUNG, S.C.; CHANG, Y.K.; LIU, J.S.; KUO, K.L.; CHEN, Y.H.; HSU, C.C.; TARNG, D.C. Metformin use and mortality in patients with advanced chronic kidney disease: national, retrospective, observational, cohort study. Lancet Diab. Endocrinol., v.3, n.8, p.605-14, 2015.

K I T W I T E E, P. ; L I M W A T T A N A N O N, S .; LIMWATTANANON, C.; WALEEKACHONLERT, O.; RATANACHOTPANICH, T.; PHIMPHILAI, M.; NGUYEN, T.V.; PONGCHAIYAKUL, C. Metformin for the treatment of gestational diabetes: An updated metaanalysis. Diab. Res. Clin. Pract., v.109, n.3, p.521-532, 2015.

MA, J.; YU, H.; LIU, J.; CHEN, Y.; WANG, Q.; XIANG, L. Metformin attenuates hyperalgesia and allodynia in rats with painful diabetic neuropathy induced by Streptozotocin. Eur. J. Pharmacol., v.764, p.599-608, 2015.

MANU, P.; DIMA, L.; SHULMAN, M.; VANCAMPFORT, D.; DE HERT, M.; CORRELL, C.U. Weight gain and obesity in schizophrenia: epidemiology, pathobiology, and management. Acta Psychiatr. Scand., v.132, n.2, p.97-108, 2015.
MCGAVOCK, J.; DART, A.; WICKLOW, B. Lifestyle therapy for the treatment of youth with type 2 diabetes. Curr. Diab. Rep. v.15, n.1, p.568, 2015.

NGUYEN, T.M.; ALVES, S.; GRASSEAU, I.; METAYERCOUSTARD, S.; PRAUD, C.; FROMENT, P.; BLESBOIS, E. Central role of 5'-AMP-activated protein kinase in chicken sperm functions. Biol. Reprod., v.91, n.5, p.121, 2014.

NGUYEN, T. M.; SEIGNEURIN, F.; FROMENT, P.; COMBARNOUS, Y.; BLESBOIS, E. The 5'-AMPActivated Protein Kinase (AMPK) Is Involved in the Augmentation of Antioxidant Defenses in Cryopreserved Chicken Sperm. PLoS One, v.10, n.7, p.e0134420, 2015.

OUSLIMANI, N.; PEYNET, J.; BONNEFONT-ROUSSELOT, D.; THEROND, P.; LEGRAND, A.; BEAUDEUX, J.L. Metformin decreases intracellular production of reactive oxygen species in aortic endothelial cells. Metabolism, v.54, n.6, p.829-834, 2005.

OZATA, M.; OKTENLI, C.; BINGOL, N.; OZDEMIR, I.C. The effects of metformin and diet on plasma testosterone and leptin levels in obese men. Obes. Res., v.9, n.11, p.662$667,2001$.

RABBANI, S.I.; DEVI, K.; KHANAM, S. Role of Pioglitazone with Metformin or Glimepiride on Oxidative Stress-induced Nuclear Damage and Reproductive Toxicity in Diabetic Rats. Malays J. Med. Sci., v.17, n.1, p.3-11, 2010.

TODD, J.N.; FLOREZ, J.C. An update on the pharmacogenomics of metformin: progress, problems and potential. Pharmacogenetics, v.15, n.4, p.529-539, 2014.

Received for publication on $20^{\text {th }}$ November 2015 Accepted for publication on $27^{\text {th }}$ September 2016 